\title{
Menumbuhkan Semangat Belajar Anak Usia Dini Pada Masa Pandemi Covid 19
}

\author{
Dewi Rayani ${ }^{1}$, Baiq Sarlita Kartiani ${ }^{2}$, Lalu Jaswandi ${ }^{3}$ \\ 1,2, ${ }^{3}$ Bimbingan dan Konseling UNDIKMA
}

\begin{tabular}{l}
\hline Article Info \\
\hline Article history: \\
Received 01 Desember 2021 \\
Publish 01 Januari 2022
\end{tabular}

Keywords:

learning motivation

early childhood

Covid 19

\author{
Info Artikel \\ Article history: \\ Diterima 01 Desember 2021 \\ Publis 01 Desember 2022
}

\begin{abstract}
The Covid 19 outbreak very significant impact on various sectors of individual life, one of which is the education sector. Where students and teachers alike do not have the readiness to do learning at this time. The government has issued a policy regarding not being allowed to hold crowds to stop the spread of covid 19. One of the programs in the education unit that is implemented to continue learning activities is to study from home. This study uses a descriptive qualitative method with the research subjects are teachers, parents and guardians of PAUD Permata Bangsa Mataram. collectiondata techniques using interviews, observation and various documentation. The results of the study show that there are several teacher strategies in fostering student learning enthusiasm during the Covid 19 pandemic, including, firstly, the teacher opens the communication tap with parents and the school by giving appreciation to parents in order to encourage parents and students who are getting bored with learning in the network, secondly conducting home visits and assessing the readiness to learn from home in terms of infrastructure, environmental situation and others. Provide fun learning tools for students when studying and make videos of student learning outcomes to foster student enthusiasm for learning.

\begin{tabular}{l} 
ABSTRAK \\
\hline Covid 19 berdanpak signfikan pada berbagai sektor kehiupan individu, salah \\
satunya adalah sekor pendidikan. Yang mana siswa dan guru sama sama tidak \\
memiliki kesiapan untuk melakukan pembelajaran dimasa ini. Pemerintah \\
mengeluaran kebijakan tentang tidak diperbolehkan melakuan kerumunan guna \\
menghentikan penuraran covid 19. Salah satu program dalam satuan pendidikan \\
yang diterapkan guna melanjutkan kegiatan pembelajaran adalah belajar dari \\
rumah. Penelitian ini menggunakan metode kualitatif deskriptif, subjek \\
penelitian adalah guru, orang tua wali serta siswa PAUD Permata Bangsa \\
Mataram. Teknik pengumpulan data menggunakan wawancara, observasi serta \\
dokumentasi. Hasil penelitian menjukkan tedapat beberapa strategi guru dalam \\
menumbuhkan semangat belajar siswa selama pandemi Covid 19 diataranya \\
yaitu, pertama guru membuka keran komunkasi efektif dengan orang tua dan \\
pihak sekolah dengan memberikan apresiasi pada orang tua guna memberikan \\
semangat pada orang tua dan murid yang telah mulai bosan dengan \\
pembelajaran dalam jaringan, kedua melakukan kunjungan rumah serta \\
melakukan asessmen terhadap kesiapan belajar dari rumah baik sarana \\
prasarana, situasi lingkungan dan lain-lain. Meyediakan alat pembelajaran yang \\
menyenangkan bagi siswa ketika kunjugan belajar dan membuat vidio hasil \\
belajar siswa
\end{tabular}
\end{abstract}

Corresponding Author:

Dewi Rayani

Bimbingan dan konseling Unversitas pendidikan mandalika, UNDIKMA Mataram

Email: Dewirayani@ikipmatarm.ac.id

\section{PENDAHULUAN}

Sudah lebih dari satu tahun dunia dilanda kegelisahan akan penyebaran virus Corona yang menyebabkan banyak danpak dalam berbagai sektor kehidupan individu. Salah satunya adalah sektor pendidikan. Aryadi mengatakan, di Nusa Tenggara barat ditemukan per 10 Februari 2021, angka positif Covid-19 di NTB tercatat 8.407 kasus Hal ini cukup merisaukan semua pihak. Pemeritahpun terus menghimbau agar masayarakat mematuhi protokol kesehatan dengan menerapkan 5M (Memakai Masker,Menjaga Jarak, Mencuci tangan dengan sabun dan 
air mengalir, Menjauhi kerumunan dan Membatasi mobiitas interaksi). Dengan ini juga, pemerintah mengeluarkan kebijakan yang berkaitan dengan kelangsungan pendidikan ditanah air, salah satu kebijakan yang masih diterapkan guna mencegah penuraran Covid 19 adalah dengan menutup sekolah dan memberlakukan sekolah dengan jaringan atau belajar jarak jauh. Hal ini dilakukan guna mengoptimalkan jalanya pendidikan selama masa pandemi Covid 19.

Guna menanggulangi hal ini pemerintah membuka berbagai ruang diskusi guna mengatasi situasi ini. Segenap kebijakan telah ditetapkan pemerintah guna meyelamatkan sektor pendidikan dari ancaman wabah Covid19 ini. diantara kebijakan yang masih diterapkan adalah dengan belajar dari rumah (BDR) belajar dalam jaringan dan masih banyak lagi. Penerapan pendidikan seperti ini harus dipatuhi oleh semua jenjang pendidikan mulai tingkat TK, SD, SMP, SMA hingga tingkat universitas guna mencegah penyebaran Covid 19. Adanya perubahan proses pembelajaran ini tentunya masih menjadi kendala bagi para guru dan orang tua dikarenakan para guru akan susah mengentrol bagaimana proses belajar anak selama di rumah dan tidak adanya kesiapan dalam pelaksaanan kebijakan. Walau sudah berjalan lebih dari satu tahun namun kesiapan inipun belum dirasa maksimal. Usaha optimalisasi akan kesuksesan pembelajaran selama pandemi inipun terus dilakukan misalkan seperti yang tertulis dalam tribu news.com yaitu penemrintah menyelenggarakan kurikulum darurat dan pembelajaran televisi. Namun semua ini masih menimbulkan berbagai danpak dan kendala tentunya. Contohnya dalam aspek komunikasi, Dalam tribunnews.com 2020/09/04 kominfo sudah bekerjasama dengan oprator telekomunikasi agar supaya dapat membangun BTS di daerah daerah sehingga semua murid di daerah bisa mendapatkan askses belajar menggunakan internet. Namun dukungan pemerintah inipun tidak serta merta dapat menjamin kegemaran dan kesuksesan belajar selama masa pandemi ini. Terkadang pembelajar menggunakanmedia ini juga dapat menimbulkan kejenuhan dan menghilangkan motivasi belajar siswa serta hilangnya pengetahuan dan keterampilan siswa, baik itu secara umum atau secara khusus, atau bahkan hilangnya kelekatan interaksi anatara guru dengan murid.

Hingga saat ini kebijakan pemerintah sudah berjalan lebih dari satu tahun, situasi dan suasana belajar di rumahpun mulai menimbulkan berbagai kendala yang dirasakan, orang sudah merasa bahwa anak -anak sudah enggan belajar dikarenakan belajar dalam jaringan tidak sebahagia belajar di sekolah dengan teman-teman dan adanya guru yang selalu memberikan semangat. Bahkan anak anak lebih banyak bermain ketika belajar di rumah, lebih banyak bermain gadget. Selama belajar dari rumah anak-anak akan beraktifitas dengan media atau HP (Handphon) sedangkan dunia sosial dan bermain anak sangatlah terbatas. Dengan demikian sangatlah penting dilakukan penelitian untuk memahami bagaimana cara menumbuhkan semangat anak usia dini.

Berbicara tentang semangat belajar, memang telah banyak dilakukan berbagai kajian tentang hal ini salah satu diantaranya yaitu upaya meningkatkan motivasi belajar siswa melalui lesson study yang dilakukan oleh Fauziah 2017 dengan subjek penelitian kelas 5 SD hasil penelitian menunjukkan bahwa siswa kelas V SD Negeri Lampageu Aceh Besar sangat antusias dan senang dengan kegiatan pembelajaran melalui lesson study yang telah dilakukan. Namun dalam kajian ini sangatlah berbeda yaitu bagaimana menumbuhkan semangat belajar anak yang belajar menggunakan jaringan dimasa pandemi covid 19 ini. Penelitian ini juga mengkaji bagaimana strategi guru dalam menumbuhkan semangat belajar anak usia dini dimasa pandemi covid 19.

\section{METODE PENELITIAN}

Penelitian ini menggunakan penedekatan kualitatif deskriptif, adapun pengertian kulitatif menurut Sugiono adalah dimana peneliti ditempatkan sebagai instrument inti. (Sugiono, 2012), Sedangkan menurut Poerwandari (2005) penelitian kualitatif adalah sutu jenis penelitian yang pengolahan datanya menggunakan analisa deskriptif, seperti transkrip wawancara dan hasil observasi. Pendapat lain juga menurut Bogdan dan Taylor (dalam Moleong, 2010) mengemukakan bahwa penelitian kualitatif adalah prosedur penelitian yang 
menghasilkan data deskriptif berupa kata-kata tertulis atau lisan dari subyek yang diamati. Sedangkan subjek penelitian ini adalah siswa dan siswi PAUD Permata Bangsa sebanyak 8 orang siswa serta orang tua, dan guru. Yang mana bagi peneliti dianggap lebih mewakili dalam menjawab pertanyaan-pertanyaan yang diberikan.

Selanjutnya Pengumpulan data adalah dengan melakukan observasi secara langsung dan mendalam dengan guru dan orang tua. Analisa data mengunakan teknik analisa deskriptif yang mengacu pada versi Milles Huberman, yaitu melalui tiga tahapan kegiatan yaitu melakukan reduksi data, kemudian penyajian data dan menarik kesimpulan atau memverifikasi data berikut komponen analisa data dalam gambar:

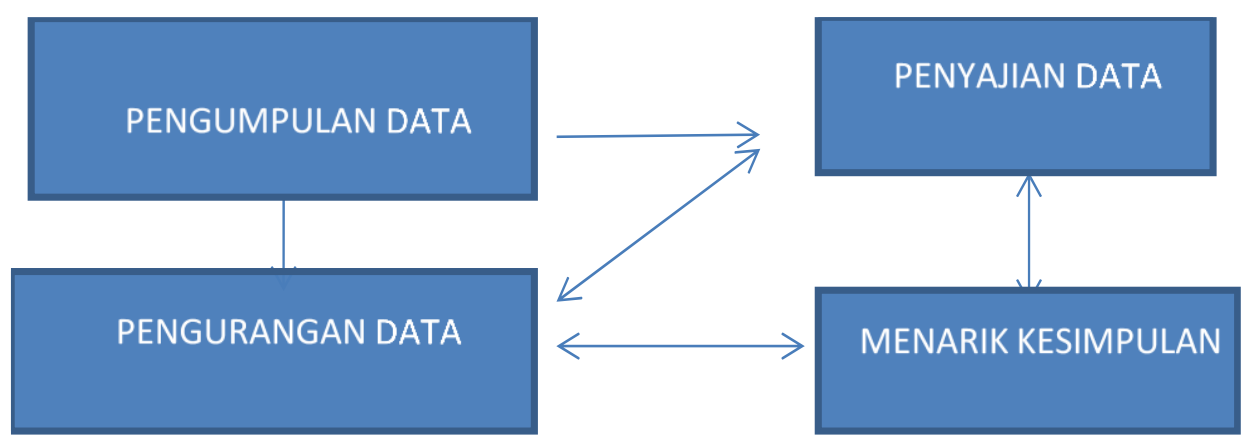

Gambar 01. Komponen Analisa Data

\section{HASIL PENELITIAN DAN PEMBAHASAN}

Berdasarkan hasil wawancara dan observasi yang dilakukan ditemukan bahwa, dalam proses pembelajaran jarak jauh yang telah dilakukan oleh siswa PAUD Permata Bangsa di awal-awal penerapan memang menerapkan secara full, bahwa pembelajaran siswa harus dilakukan di rumah dan akan didampingi oleh orang tua. Setiap awal pekan orang tua datang mengambil tugas siswa ke sekolah dan guru menjelaskan secara langsung pada wali murid (orang tua) bagaimana cara megerjakan tugas tersebut. Bentuk tugasnyapun berbeda-beda dalam setiap pekannya, hal ini dilakukan guna meminimalisir rasa bosan dan kejenuhan siswa dalam mengerjakanya. Adapun pengawasan dilakukan guru dengan berkordinasi dengan orang tua melalui media yaitu HP (handphone). Selanjutnya setelah beberapa bulan berlangsungnya pembelajaran dari rumah ini guru mulai melakukan kunjungan setiap akhir pekan pada setiap siswa secara bergantian.

Siswa tetap belajar secara sendiri-sendiri di rumah masing-masing (tidak berkelompok). Pada kesempatan ini juga guru memberikan tugas pada anak-anak sesuai dengan kurikulum yang telah ditetapkan. misalkan tugas yang diberikan adalah menggunting, mewarnai gambar, menghitung jumlah beda, membuat vido rekaman, bernyanyi dan lain-lain. Penerapan pembelajaran jarak jauh kali ini diterapkan oleh PAUD Permata Bangsa merupakan tahun kedua selama pandemic melanda, berbagai hal telah dilakukan untuk tetap membuat siswa bersemangat dalam mengikut kegiatan belajar mengajar walau penerapannya berbeda dari biasanya. Aturan pememrintah yang melarang kegiatan berkerumunan guna mencegah penyebaran covid 19 ini haruslah dipatuhi. Terdapat beberapa strategi yang telah diterapkan PAUD Permata Bangsa guna mempertahankan semangat belajar peserta didik.

\section{a. Berbagai metode guru dalam menumbuhkan serta mempertahankan semangat belajar anak usia dini.}

Berdasarkan hasil wawancara yang telah dilakukan terdapat beberapa metode/strategi yang dilakukan guru dalam menubuhkan semagat belajar siswa, yaitu diantaranya adalah :

1) Membuka keran komunikasi efektif dengan orang tua

Dalam penerapan pembelajaran jarak jauh yang dilakukan sekolah adalah tidak lepas dari bantuan oang tua, dengan demikian komunikasi efektif dengan guru sangatlah menentukan kebehasilan pembelajaran tesebut dan dapat memberikan motivasi pada 
anak dan oran tua, dalam hal ini yang dilakukan oleh sekolah adalah memberikan motivasi dan apresiasi kepada kedua orang tua tentang bagaimana kesadaran orang tua dalam keterlibatan ketika proses belajar mengajar anak di rumah. Guru seringkali memberikan apresiasi kepada orang tua, hal ini tergambar dari hasil wawancara dengan salah seorang wali murid, berikut hasil kutipan wawancara tersebut :

“ saya merasa bahwa sekolah memberikan motivasi kepada kami ya... setidaknya sebulan sekali, ibu guru selalu memberikan ucapan motivasi pada kami dengan mengatakan... terimaksih ibu karena telah mendampingi ananda belajar dengan baik, kemudian juga disampaikan " mohon bantuanya nanti ananda akan diberikan tugas seperti ini.." nah kalimat guru ini saya rasa memberikan semangat untuk kami dalam mendampingi anak belaja di rumah.

Berdasarkan hasil wawancara tesebut diatas, hal ini merupakan salah satu upaya yang dilakukan sekolah guna menghangatkan komunikasi guru dengan orang tua agar tecapainya hasil yang maksimal bagi siswa dalam proses belajar jarak jauh. Dengan adanya hal ini juga orang tua menjadi tidak segan kepada guru untuk menceritakan keluh kesah selama belajar di rumah, terutama bagi orang tua yang memiliki pekerjaan tetap yang bukan hanya sebagai ibu rumah tangga saja. Misalkan masalah waktu, biasanya orang tua yang bekerja di luar rumah hanya dapat membantu dan mendampingi anak anak secara full pada hari libur ( sabtu dan minggu) dan dengan ini orang tua dapat mengajukan keringanan bagi anak dalam mengumpulkan tugas dan sebagainya. Capaian target belajar anak juga dapat dikomunkasikan oleh orang tua secara terbuka dengan guru ,misalkan masalah mengurangi atau menambah target belajar anak. Dengan demikian strategi guru dengan mengaktifkan dan membuka komunikasi efektif ini dirasa sangatlah membantu dalam mempertahankan semangat belajar anak, karena dengan adanya orang tua yang semangat mendapingi anak belajar maka anakpun akan antusias dan semangat dalam belajar. Hal ini sejalan dengan hasil penelitan yang dilakukan oleh Nur cahayati (2020) tentang pentingnya peran orang tua dalam mendampingi anak belajar di rumah selama pandemi.

2) Melakukan kunjungan rumah

Kunjungan rumah ini merupakan cara yang lain juga yang dilakukan guru dalam memotivasi anak, selain itu juga kunjungan rumah yang dilakukan guru ini dijadikan sebagai ajang asissmen yaitu mempelajari berbagai kendala siswa dalam belajar. Misalkan suasana rumah yang kondusif atau tidak saat belajar di rumah, atau dalam satu rumah terdapat dua siswa menggunakan satu HP dalam proses belajar mengajar, tentu saja ini akan memiliki kendal yang signifikan. Dengan adanya home visid ini guru dapat memahami berbagai kendala yang dihadapi siswa saat belajar jarak jauh.

Dengan adanya kunjungan ini juga, guru dapat memahami bagaimana media komunikas yang berupa HP (Handphon) ini dapat membuat menjadi mudah lelah saat belajar. Dengan demikian guru bisa menggunakan alternative yang lain, seperti memberikan penugasan yang tidak menggunakan media.

3) Membawa beberapa alat permainan (APA) yang menarik

Selain melakukan asismen saat kunjungan rumah,untuk tetap menumbuhkan dan mempertahankan semangat belajar anak guru juga tidak lupa menciptakan suasana belajar di rumah yang menyenangkan dengan membawakan beberapa alat permainan yang menarik ke tempat tinggal siswa. Hal ini didukung oleh hasil wawancara dengan salah seorang guru yaitu

" kami selalu membawa beberapa alat permainan yang berbeda beda setiap kunjungan, tentunya alat permainan ini mendukung berbagai aspek perkembangan anak anak. ya kita juga tahu bahwa anak-anak masanya masih masa bermain jadi kami kemas pembelajaran dengan cara bermain juga namun tetap ada unsur edukasinya"

Pada usia anak-anak fungsi bermain mempunyai peranan penting bagi 
perkembangan anak. Jika pada orang dewasa sebagaian besar dari aktifitas yang dilakukan adalah diarahkan pada pencapaian tujuan dan prestasi dalam bentuk kegiatan kerja, hal ini sangat berbeda dengan anak-anak yaitu berbentuk aktifitas bermain hal ini selalu dikembalikan pada asumsi yang mengatakan bahwa dunia anak- anak adalah dunia bermain. Dengan bermain anak akan mengembangkan berbagai imajinasi dan potensi yang dimilikinya apalagi didukung oleh adanya alat belajar yang dikemas dalam proses bermain anak. Adapun teori yang medukung tetang peran permainan anak adalah salah satunya tentang teori fenomenologis yang dikemukakan oleh professor Kohnstamm (dalam kartini, 2007) yang mengatakan bahwa permainan merupakan suatu fenomena nyata yang mengandung unsur suasana-permainan yang di dalamnya terdapat beberapa faktor yaitu kebiasaan, harapan kegembiraan unsur ikhtiar dan siasat untuk mengadapi hambatan dan perlawanan. Dengan demikian permainan sangatlah penting bagi anak dalam mengembangkan diri dan potensi yang dimilikinya.

4) Membuat video hasil belajar

Selain beberapa hal di atas guru juga meminta siswa dan wali untuk membuat video belajar. Hal ini termasuk kegiatan yang digemari siswa dan dapat menumbuhkan semangat belajar siswa selama belajar dari rumah. Video belajar yang dibuat oleh siswa memiliki durasi yang tidak terlalu lama, orang tua dan siswa bekerjasama membuat video belajar, berdasarkan hasil wawancara dengan orang tua, ketika siswa melihat kembali hasil video yang dibuat dan dikirimkan kepada wali kelas, siswa terlihat antusias dalam mengerjakan video tersebut, misalkan contoh video adalah ketika siswa membaca dan menghafal surat-surat pendek dan menampilkan hasil kerja yang telah dilakukan. Selain itu juga memberikan caption yang membuat siswa bahagia dan semakin semangat belajar, misalkan pujian serta apresiasi guru ini membuat siswa semakin giat. Pujian ini dapat kita katakan sebagai reward atas hasilkarya yang dilakukan.

Berikut hasil wawancara dengan salah seorang guru yaitu:

"kami melihat anak anak senang kalau dipuji ketika hasil vidio belajarnya dikrimkan. Pujian ini kami berikan menggunakan VC (voice note) tidak jarang juga kami kirimkan juga emoticon penyemangat untuk anak anak. Saya rasa dengan ini anak anak semakin semangat dan bahkan mengirimkan tidak hanya satu vidio tapi lebih “

Berdasarkan hasil wawancara diatas jelaslah bahwa pujian serta apresiasi guru ini merupakan penguat untuk membuat siswa semakin semangat dalam belajar. Hal ini juga sejalan dengan hasil penelitian yang dilakukan oleh Rian putri (2013) dengan judul studi tentang pelaksanaan pemberian rewad dalam meningkatkan motivasi belajar kelompok A di TK Islam Al azhar Surabaya. Dengan hasil penitian menunjukkan bahwa motivasi anak kelompok A semakin meningkat ketika guru memberikan rewad berupa komunikasi verbal ataupun non verbal, misalkan pada komunikasi verbal berupa pujian dan kata-kata penyemangat sedangkan non verbal berupa pemberian stempel atas hasil belajar siswa.

\section{b. Temuan Lain Dalam Penelitian Ini}

Jikalau dikembalikan dalam konteks belajar bahwa belajar merupakan adanya suatu perubahan yang progresif dalam diri siswa. Dalam Dictionary of Psychology Chaplin membatasi belajar dalam dua rumusan yaitu perolehan perubahan tingkahlaku yang menetap sebagai akibat dari latihan dan pengalaman. Dan yang kedua adalah proses memperoleh respon sebagai akibat adanya latihan khusus (Muhibbin , 2014). Kembali lagi pada sistem pembelajaran yang ada di Permata Bangsa yaitu sekolah saat ini menerapkan atau mengembangkan tentang bagaimana pentingnya pendidikan karakter dalam diri siswa, namun dengan adanya belajar jarak jauh siswa-siswi mengalami penurunan dalam segi pendidikan karakter, hal ini didukung oleh pengakuan guru, berikut kutipan yang didapat berdasarkan hasil wawancara 
" sebenarnya motivasi siswa itu saya rasa dapat kita jaga dan tingkatkan dengan, metode yang sudah diterapkan, hanya saja disini yang kurang adalah bagaimana menanamkan sisi nilai karakter dalam diri anak. Dengan belajar dari rumah dan system jarak jauh ini saya rasa agak susah"

Hasil intervieuw diatas juga didukung oleh beberapa pernyataan orang tua yang mengakui dan bahkan mengeluhkan tentang bagaimana perilaku anak-anak selama berada di rumah berikut hasil kutipan wawancara orang tua

“ Kenapa ya anak saya sekarang ini jadi gadjet melulu, kedisiplinanya kurang, waktu belajar malah minta main dulu baru mau belajar.

Berdasarkan hasil wawancara ini merupakan, terdapat danpak bahwa terjadinya penurunan nilai positif yang dialami oleh siswa ketika siswa belajar dari rumah. Dan hal ini dirasa sangat meresahkan untuk anak. Mengingat bahwa masa anak-anak adalah masa keemasan yang harus selalu dipupuk berbagai keterampilan yaitu baik sikap maupun nilai kognitif. Pada usia ini juga sangatlah efektif untuk menanamkan berbagai ilmu yang bermanfaat. Hal ini dapat dijadikan sebagai pondasi yang kuat guna mendukung kehidupan anak pada masa mendatang.

Adapun menurut Menurut Undang-Undang No.20 pasal 1 butir 14 tahun 2003 tentang Pendidikan Anak Usia Dini (PAUD), pendidikan karakter dalam PAUD adalah suatu upaya pembinaan yang ditujukan kepada anak sejak lahir sampai dengan usia 6 tahun yang dilakukan melalui pemberian rangsangan pendidikan untuk membantu pertumbuhan dan perkembangan jasmani dan rohani agar anak memiliki kesiapan dalam memasuki pendidikan lebih lanjut. Undang-Undang No.20 tahun 2003 pasal 9 ayat 1 menegaskan setiap anak berhak memperoleh pendidikan dan pengajaran dalam rangka pengembangan pribadinya dan tingkat kecerdasannya sesuai minat dan bakatnya. Hal ini jelas tergambar bahwa pendidikan karakter menjadi bagian yang penting dan tidak terpisahkan dalam mendidik anakusia dini.

Berbagai keluhan orang tua dan analisa guru tentang anak adalah dapat dikatakan sebagai danpak dari pembelajaran jarak jauh yaitu anak tidak belajar sebagaimana mestinya. Anak memang mendapatkan berbagai tugas namu motivasi anak untuk mengerjakan tugaspun perlu mendapat perhatian yang lebih dan kerjakeras guru serta kolaborasi orang tua. Pada ranah pendidiikan karakter biasanya anak akan lebih mudah menyerap ketika belajar bersama-sama dengan teman seusia, anak-anak bisa saling berlomba-lomba dalam menghafal serta mencontoh hal-hal yang baik yang biasanya terus dikembangkan selama anak belajar di sekolah. Misalkan mulai dengan kedisiplinan anak saat belajar dan bermain. Menghafal ayat ayat pendek, serta berbagai doa sehari-hari dan bagaimana interaksi anak dengan guru dan teman teman. hal ini adalah merupaan sarana pendukung dalam mengembangkan karakter serta religiusitas anak usia dini.

\section{KESIMPULAN}

Berdasarkan paparan hasil penelitian ini maka dapat disimpulkan bahwa, terdapat beberapa bentuk stategi guru menumbuhkan semangat belajar siswa selama belajar di rumah adalah dengan membuka keran komunikasi efektif antara orang tua dengan guru, hal ini dijadikan sebagai penyampai keluh kesah serta berbagai hal yang berhubungan dengan kendala dan kemudahan saat siswa belajar di rumah, kedua adalah melakukan kunjungan rumah, home visid ini dijadikan sebagai kesempatan asismen dalam menganalisa berbagai hal baik sarana prasarana pendukung dan penghambat berjalanya pembelajaran jarak jauh atau belajar dari rumah. selain itu juga kunjungan rumah juga tetap dijadwalkan guru dengan membawa berbagai alat bermain yang menarik guna tetap mempertahankan semangat anak dalam belajar dan yang terakhir adalah dengan meminta wali/ orang tua untuk membuat media hasil belajar anak berupa video dengan durasi yang singat. Meski hal ini terlihat sederhana namun berdasarkan kajian peneliti semua hal ini dapat meningkatkan dan mempertahankan motivasi anak belajar selama pandemi covid 19 yang mana anak harus belajar dari rumah. 


\section{DAFTAR PUSTAKA}

Cahyati, N., \& Kusumah, R. (2020). Peran Orang Tua Dalam Menerapkan Pembelajaran Di Rumah Saat Pandemi Covid 19. Jurnal Golden Age.

Depdiknas .2003. Undang-undang RI No.20 tahun 2003.tentang sistem pendidikan nasional.

Fauziah, Intan Safiah, Syarifah Habibah. ( 2017) Upaya Meningkatkan Motivasi Belajar Siswa Melalui Lesson Study Di Kelas V Sd Negeri Lampagen Aceh Besar. Journal. Jurnal Ilmiah Pendidikan Guru Sekolah Dasar FKIP Unsyiah Volume 2 Nomor 1

Moleong, Lexy J. (2013). Metode Penelitian Kualitatif. Edisi Revisi. Bandung : PT. Remaja

Kartini Kartono. (2007). Psikologi Anak (Psikologi Perkembangan). Bandung : CV Mandar Maju.

Syah, Muhibbin. (2014). Psikologi Pendidikan. Bandung: PT. Remaja Rosdakarya.

Sugiono . (2012). Motode Penelitian Kombinasi (Mixed Methods).Bandung: Alfabeta.

Rimbarizki, R. (2017). Penerapan Pembelajaran Daring Kombinasi Dalam Meningkatkan Motivasi Belajar Peserta Didik Paket C Vokasi di Pusat Kegiatan Belajar Masyarakat (PKBM) Pioneer Karanganyar. J+ PLUS UNESA, 6(2)

Rian Putri Hapsari , (2013) Studi Tentang Pelaksanaan Pemberian Reward Dalam Meningkatkan Motivasi Belajar Kelompok-A Di Tk Islam Al-Azhar. Jurnal BK Unesa. Volume 04 Nomor 01 Tahun 2013. 274-284 27435

Kompas.com dengan judul "Persentase Kematian Covid-19 di NTB Tertinggi di Indonesia karena Kurang Tracing", https://regional.kompas.com/read/2021/02/11/10313441/persentase- kematian-covid19-di-ntb-tertinggi-di-indonesia-karena-kurang?page=all.

www.tribunnews.com/pendidikan/2020/09/04/ragam-upaya-pemerintah-tingkatkan-kualitaspembelajaran-jarak-jauh.Reynas Abdila 